\title{
Aspects Of Paiter Suruí Oral Art
}

\author{
Magda Dourado Pucci \\ ASCA - Amsterdam School of Cultural Analysis
}

Paiter Suruí oral art, constituted of narratives, pajé chants, ritual chants and "contact" ${ }^{2}$ songs, constitute an intricate anthropological body of sounds that are used in multiple types of oral discourse with different levels of musicality. The sounds found in the Arampiã Archive, ${ }^{3}$ recorded by anthropologist Betty Mindlin, are true enigmas waiting to be unveiled like clues to a wider comprehension of the singing of the Paiter Surui and their history. This process cannot be restricted to a translation of the lyrics, because the Paiter Suruí express themselves with sounds that are difficult to present in a Western musical score because the timbre and vocal quality intensely "modulate" intonations and sound effects to give sinuosity and expressiveness in their interpretation to the audience. There are no words in the phonoaudiological discipline to describe this form of sing-talk. It would be what Zumthor called vocality 4 to refer to voice in an anthropological context, voice as a sonorous motif of rites, capable of promoting love, hatred, trance, commotion, rebellion or contravention. It is in this vocal scope that the poetic essence becomes the greater catalyst and it is where the relationship between sensitive and

\footnotetext{
1 pajé - a kind of shaman, a person who has the power to invoke the natural spirits to cure someone

2 The Suruí remained isolated until 1969, when they had their first peaceful contact with a FUNAI expedition headed by Apoena Meireles and his father Francisco Meirelles.

3 The Suruí archive is part of the Arampiã Archive that contains narratives and music of other indigenous people like Gavião-Ikolen, Tupari, Macurap, Jabuti, Arikapu, Ajuru, Kanoé, Kampé, Zoró, Arara, Sateré-Mawé and Tremembé. Part of this material, especially the narratives, was translated by Mindlin, with the indigenous peoples with whom she has been conducting projects and educational workshops for many years.

4 The connection between lógos and mélos, between myth and music, between singing and speaking, between text and sound was supported by Paul Zumthor's (2007) concepts, which allowed a new understanding of the voice as anthropological data, of language conveying voice as an organizer of sonority, and of the voice in its symbolic space, which he called vocality.
} 
intelligible, between the visibly and invisibly present worlds takes place, mainly in indigenous environments. In Paiter Surui poetry, there is musicality not only in the songs, but also in the narratives due to the tonal feature of the Tupi-Mondé language, which is rich in onomatopoeias and ideophones ${ }^{5}$, and used to create sounds for movements of some of the characters in Paiter narratives. There are also exclamations used as verbs which imitate animals of the forest and movements of spiritual beings of the other world that also can be considered a kind of ideophone.

Some examples can be heard on the audio excerpt ${ }^{6}$ :

a) Wuu!...wuu!...iaká mawud nã yã taje e

Translation: Flew, flyyyyying, became a nambu bird, they say

b) Etigate iá, ta-je wuuuuuu!...trug, pug!,...Pamo ey anarub yã taje e

Translation: Grabbed his head and said that he came flyyyyyyyying, trug, pug, the old people were noisy, very very noisy, and that is what they say.burug, bon...bon, poropang. Hu...lobeei koranie! - iã ta-je

Translation: The mother hawk, grabbed...grabbed the branch of the tree, so say the ancestors.

With these elements, the Paiter Surui recreate moments of their mythical history and reveal that not all myth is fable, because reality is always lurking, showing its presence through metaphors and archaic words, because for the myths, Paiter speakers d not use the everyday language.

5 Ideophone is understood as "a vivid representation of an idea in sound. A word, often onomatopoeic, which describes a predicate, qualificative or adverb in respect to manner, color, sound, smell, action, state or intensity.' Ideophones evoke sensory events. Reduplication figures quite prominently in ideophones, often conveying a sense of repetition or plurality present in the evoked event. A well-known instance of ideophones is onomatopoeic words, i.e., words imitating the sound (of the event) they refer to. Some ideophones may be derived from onomatopoeic notions. A case in point is the English ideophonic verb to tinkle, which is likely to be derived from an imitation of a brief metallic sound. It is maintained by some (e.g. Kilian-Hatz 2001:157, Kock 1985) that ideophones denote a complete utterance and as such have a sentence-like character. However, reports from other languages (Cantonese, Yoruba, Hausa, Ewe, to name a few) challenge this statement, showing instead that ideophones can be fully integrated into sentences, just like ordinary verbs and nouns. This difference of opinion is attributable to the fact that languages vary in the way that they make use of ideophones. Conversely, this may be evidence that several distinct linguistic phenomena have been called ideophones, and that the concept therefore needs to be better defined to be useful in scientific discourse. Doke 1935:118

6 Part of the myth Pamo ey, transcribed by Betty Mindlin and Ipokaran Suruí 
This way, an intricate relationship is established between music and narrative, between speech and chant; between the voice and the myth that together compose what I define as "sonorous mythologiques", as a reference to Claude Lévi-Strauss's book Mythologiques 1(2004).

To better understand how the "part chant part speech" works, I visited the Surui region several times over three years and worked with some of them to translate myths and understand the function of songs in their narratives. These "sonorous mythologiques" relate to the trajectories of heroes, clan sagas, inter-tribal wars, and conflicts with invaders - revealing facts of several layers in the deepest history of this people. Their characters come to life, releasing ditties from within narratives, as is the case of the spirit-bird Winih ${ }^{7}$ and the jaguar meko. These characters' ditties are syntheses of these long narratives that work as "sonorous reminders."

The Winih chant - a man who turned into a spirit-bird - refers to the mythological being that descends to earth and allures children with corn pancakes to take them to the heaven. It sounds like a warning whose text reinforces the threat.

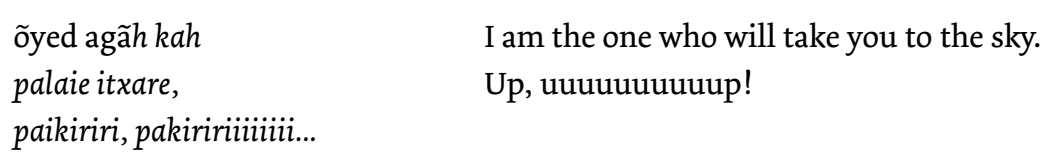

Click to hear: Winih song, by Perpera

Click to hear Meko song, by Mamboar

With a highly nasal voice and the melodic outline composed by semitone intervals, the idea of "suspense" is created. In the context of the myth, these sounds reveal the character who sings it, an imaginary being who scares everyone off with their magic power to take children to the heaven. At the moment of interpretation, we found difficulty in defining the meaning of paikiririiii, because it is an onomatopoeia - a sound representation of Winih "flying" with the children, who are "enchanted" by the sound he made. The

7 Song that is part of Winih and the Deadly Flute narrative (Betty Mindlin version). To the Paiter Suruí, the animals are spirits like Winih, a man who turned into a spirit-bird and in order to take revenge on the Two Brothers (demiurges) - Palob and Palob Leregu - kidnapped children and took them to heaven, in one episode in the myth. Although detached from the narrative, the song is a way to warn children to behave, otherwise Winih can come to catch them at any time and take them away forever. 
rising sound accentuates the imaginary feature about the action of flying high, to the sky.

The melody of the Meko (jaguar) song also has a rhythmic division that expresses the intention of threat, when the Deer sent by Palob - a cultural hero - (literally, our father) sends the Deer to the house of the Meko to bring back the bones of the men it gobbled up. With the bones, Palob will remake humanity by puffing smoke over them. But the Jaguar, suspicious of the attitude of the Deer, "sings" its threat with the following lines:

$\begin{array}{ll}\text { Engaba pamãi aré, oi kaled mã } & \text { I am the jaguar! } \\ \text { bi kü erá ongatchar } & \text { Animals have warned me } \\ \begin{array}{l}\text { awabekaté ongatchar } \\ \text { bi aadauuuuuu }\end{array} & \text { Animals said you will come here } \\ \end{array}$

The sound [biau], with the [a] and the long [u] with rising and falling glissando is an ideophone, because the word does not exist, it has been invented by the narrator to sonorously "illustrate" the bite of the jaguar when swallowing the prey. It causes fear in the listener, emphasizing the threatening tone of the jaguar.

Winih and Meko are clue figures from long and old narratives and their songs recall those mythical situations. The use of this dramatic form to present the narratives is not exclusive of Paiter Surui oral art. This theatrical approach is found in other Brazilian indigenous peoples like the Xavante in the Pimentel Barbosa Reserve, where:

"the speaker becomes the embodiment of those who have spoken in the past, he brings the perspective into the present". Warodi, in a theatrical myth-telling to the children and I, temporarily assumed the voices of various characters surrounding the parinaila's creation. However, when speaking with their voices, he did not go so far as to lose himself in the other's personae. (...) Warodi also retained his individual, present time perspective by making a number of observations about the telling, as well as didactic comments". (Graham 2003:196)

There are also the $w a w \tilde{a}^{8}$ songs that appear not to make any logical sense, since they refer to supernatural beings. Nevertheless, they unveil a rich cosmogony that is the origin of Paiter Surui beliefs and their worldview. In

8 wawa is the term used by the Paiter Suruí for the function of a shaman. 
this spiritual environment, where shamans and animals "dialogue", there are sound movements that can be called chants, prayers, whistles, sighs, whisperings, silences, speeches or interjections. They are a rich ancestral heritage, which cannot always be understood from a strictly musical point of view. As was confirmed by ethnomusicologist Acácio Piedade, when researching the music of the Ye' pâ-Masa, people of the Upper Rio Negro:

the limits between speaking and singing are very dissimulate, difficult to define and guided analysis using phono-acoustic musical terminology is not always enough - therefore there is a need to adopt new concepts to cover this variety of vocal forms. (Piedade, 1997)

In the pajé songs (wãwa) it is common to use very deep sounds to copy the sound of a jaguar (mummmummm) and other more guttural ones like uuhuuhuhuuhhh along with glottal strokes which resemble Tuva knight songs. There are glissandos between words, which create sounds that slide from side to side, almost producing a spoken melody or a spoken chant, like Schoenberg's Sprechgesang.

Considering this melodic speech, it is almost impossible to create a musical score for the diverse oral genres of the Paiter Suruí. To do so, I believe that contemporary music scores that use signs and symbols should be used instead of musical notes in scores, with intentional overlapping lines, establishing a great sonorous texture, as in this excerpt of a music sheet by the composer Stockhausen:

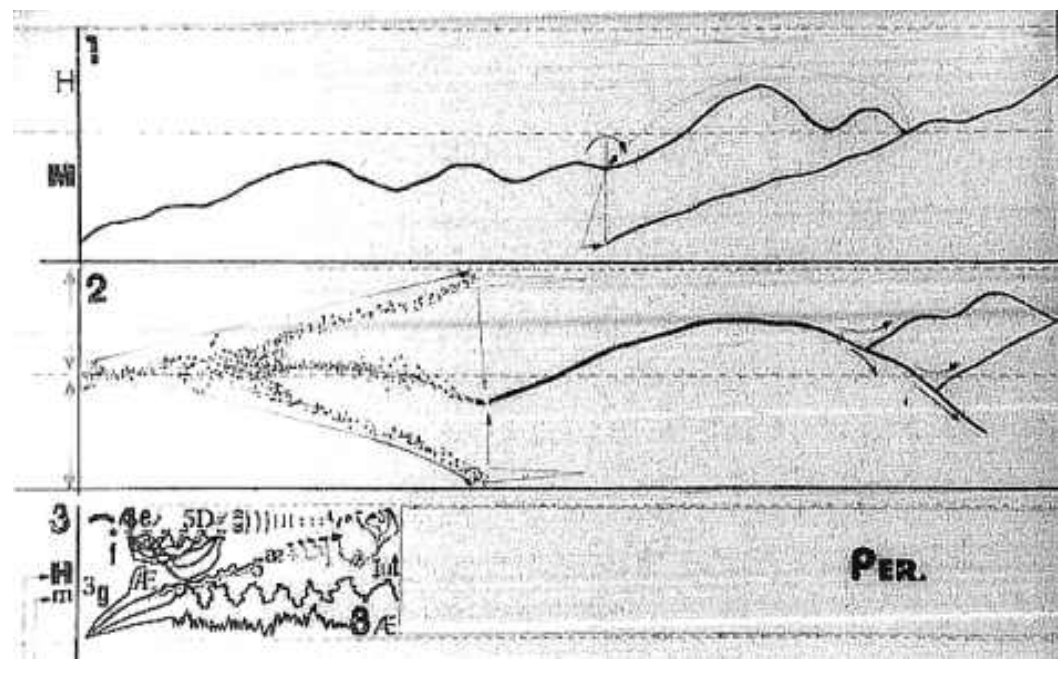


In fact, our vocabulary has no precise way to explain these forms of singing and speaking by some indigenous cultures. In the book "Why Suyá sing?", Anthony Seeger described very well relationships among the different vocal art forms performed by the Suyá people (Xingu) and criticized the separation of the various disciplines that study music and speech in these cultures.

"The relationships among Suyá genres demonstrate how the separation of speech and music distorts both of them. Instruction, oratory, invocations and songs all structure time, tone and timbre. The relationship of the texts to these structures (whether inserted into them or creating them) varies among the genres, and can only be understood when the entire gamut of music and speech is examined. Rather than studying forms of speech and song singly, in the supreme isolation of different scholarly disciplines, we should be studying them as interrelated genres that employ phonetics, text, time, tone, and timbre in different but possibly systematic ways. By showing how the genres are interrelated and illustrating their use in their social contexts we will be better able to analyze any given form and break out of the disciplinary isolation that has hampered the analysis of actual performances". (Seeger, 2004:50-51)

The Paiter Surui archive presents many examples of what could be considered an "uninteresting and little melodic" chant, as the first European travelers often described indigenous music. It is actually another form of vocal expression, as important as songs that have more melos. This chant-speech was once considered one of the leading indicators used to characterize "primitive" peoples. It is now recognized that it constitutes part of an orality of great complexity, given its highly symbolic status, as well as the sophisticated forms of poetic elaboration. In some cases, it is possible to identify meter, rhyme, repetition and tout ensemble, sound resources that can be defined as poetic forms and not mere phonetic coincidences. But they must all be linked with specific functions, such as healing or myth telling.

Jonathan Hill pointed out that the "ritual power in the Wakuénai society is a poetic process of using the musicality of spoken, chanted and sung speech to explore the nuances and hierarchical levels of mythic meaning" (...) In Wakuénai ethnopoetics, there is no categorical distinction between "mythic meaning" and "language music", since both more and less powerful modes of poetic speaking are sensuous, performative processes in which musical 
sounds and mythic meaning act upon and transform into one another" (Hill, 1993:201).

Not everything that I understand as "being music" is considered music by the Paiter Surui to whom, it seems, speech can be music. I can also say that there is a poetic quality that can be performed in different ways according to its function in Suruí society.

It is almost impossible to distinguish music from poetry in Suruí oral art. They are two sides of the same coin, mainly because almost all Surui musical production is vocal. In the Surui language, there is no word for "music," but there is one for "chant" which, according to Uraan, one of my translators, is merewabe. All terminology associated with music is associated to the chant intrinsically:

- chant: merewabe

- rhythm: merewabe sameh

- melody: merewabe kui

- beautiful song: merewawe paor

- happy song: merewawe kuyah

- sad song: merewawe pereib

The word used to define music is the same that refers to chant (verbal information). They are like synonyms. If chant, rhythm and melody is music as well as the elements that integrate Surui narrative, whenever I refer to music, I will be referring to poetic forms of expression, understanding that both are two sides of the same coin, reinforcing the data that music and poetry are elements of an imbricate sound system always connected with Surui society.

Surui oral art is constantly moving across these frontiers. Is this what Anthony Seeger (2004) calls "the musicality of speech" in his study of the Suyá Xingu? Would this be the feature about which Basso speaks in terms of the Kalapalo narrators? (1985)

"The mythical narrative operates through the use of specific features of spoken language that include a special use of grammatical elements, the focus of action, time and verbal categories, spatial imaging, all in the direction of creating a socially shared fantasy, which allows locating a thought in terms of mythic time and space. In ritual music, sound acts as a symbolic code modeler, also toward the creation of such parallel realities". (Basso, 1985: 8).' 
Although the traditions of the Paiter Suruí, the Suyá and Kalapalo are different, "spoken song" seems to be a resource often used in healing rituals, the So pereiga, the chant of spirits vocalized by the pajés 9 . Although it has a fixed rhythmic and melodic structure, the wãwa chant sounds like rhythmic speech, with strong musicality.

In the Paiter Suruis social life, wãwã has a central role, because his intrinsic connection with the supernatural gives him special powers. According to tradition, only shamans can recognize the different categories of forest spirits: goan ey (water spirits) and gora ey (heaven spirits) ${ }^{10}$. When invoked, they can avoid diseases caused by unwelcoming spirits or even drive them away from the community before they come too close, Therefore, they kept a series of rituals based on the constant dialog between real and imaginary worlds.

The voice of the pajé employs archaic terms that are not always comprehensible. They resemble sound-words that unveil features of the spirit that "soars over" the pajé, but do not result in discursive consistency, for they may also be related to mythical contents.

\section{Click to hear: So ey perewa Đatikad, by Perpera}

With whispered words, rhythmic speech and melodies "puffed" by the so ey, the Paiter Suruí shamans healed and took care of their people in the village. The Paiter pajé chants (wãwã perewabe) are linked to the healing songs (So pereiga), to the rituals of scaring unwelcome spirits (Peixo ey) and the So ey ate ditties that claim protection for the whole village. The songs sung by wãwa are known by many, but only the shaman can perceive when the spirit wants to "appear".

The rhythmic speech of the elder men - the korub ey - sometimes sounds like the sprechgesang created by Schoenberg, ${ }^{11}$ who studied the "musicality of

9 The Paiter Suruí shamans are people who were initiated by a painful process that requires great endurance and courage. "At times they are bitten by snakes and as they absorb the venom experience moments of hallucinations that induce "encounters with others beings of the Marameipeter (literally a deserted road, without detours) where the ground is soft. There are many palm trees, a large lake with red water. According to Perpera, a Surui pajé who has passed away, in this mythic place, there are many layers of heaven, "one securing the other, all of them are stuck together, round, domed, that fit together, descend, one holds the other. Each sky has its life and its spirits - So - which help to hold up the heavens" (translation of transcription by Mindlin, 2007:210).

10 The goan ey and gora ey are beings that have been human and turned into animals. As they go down the vine ladder they whisper (puff) songs to the wãwã.

11 Sprechgesang, a German word meaning "spoken song," sung speech, “or” sing-speak." This was an 
speaking/ speech," i.e. words as music and not syntactic content. These connections seem to repeat themselves throughout time as founding principles of certain societies or as necessary artistic forms at certain moments. They may indicate a sense of timelessness, which traditional ethnomusicology understood as a "primitive" form of expression, but which I consider essential to understanding the orality of any group or person at any time.

\section{spoken-chant chanted-speech}

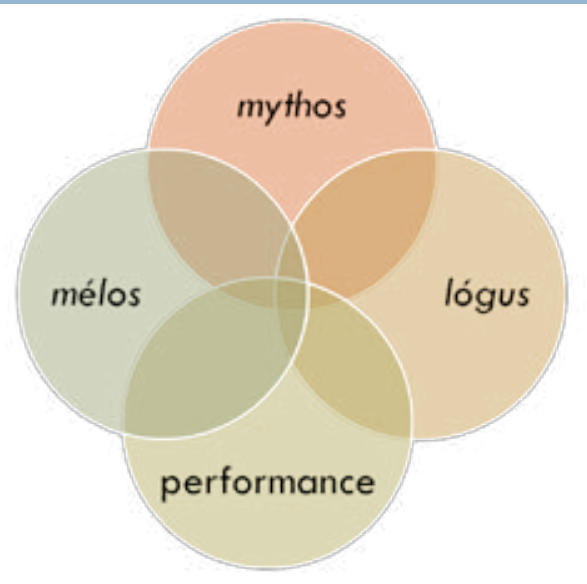

The spoken-chant (or sung-speech) has the ability to take the listener into other dimensions, making them "change time". This use is essential to understanding the role of storytelling in any society, whether urban, Amazon or from the Brazilian sertão. The narrator is also a singer, soundman, and actor, i.e., a performer, as anthropologist Carmem Junqueira accounts in the narration of a Kamayurá people in Xingu:

"The teller dramatizes the display reproducing sounds of nature - thunder, rain, wind - and animates the dialog of animals with a special voice, giving each event or character a distinction. Gestures, whistles, and pauses help recreate cheerful or scary, comic or sad atmospheres, i.e., one that best suits each passage. It is drama in which a single artist performs all the roles, and takes care of the special effects.» (Junqueira, 1991:61) 
The art of narrating is an aesthetic expression found in several cultures and reveals great sonorous diversity. It was through the doors of this millennial practice that I initiated my studies of the Paiter Surui vocal expressions, which have been undergoing great changes the pajés and narrators have converted to Evangelism, a growing phenomenon in Rondônia. A gap has been created between the generations who were not brought up with orality, which has made them unaware of the emblematic contents of the Paiter Surui history. That is why the digitalization, organization, cataloging and returning of material to the Paiter Surui Archive have been so important. This has allowed this material to be used in indigenous schools, so that part of the symbolic tradition can be effective in Suruí life. It is not only a question of informing the present with the past, but encouraging the elders to recall the reactions that the songs and narrations promoted in Surui life. The hearing of the archive has instigated elderly Suruí to retell old myths using these rich poetic resources, at a time when the Tupi-Mondé language of the Paiter is being systematized. This allows these precious poetic forms to be taught to children by the voices of korub ey, the only ones able to decipher archaic terms and their connections with the myths.

However, this "re-enlightening from the narratives" is not intended to freeze traditions, to the contrary, it may stimulate a new generation of storytellers, if a deeper knowledge of the language is encouraged with help from linguists who are sensitive to the Paiter Surui poetic forms. This was possible during some translation sessions when it became possible to better understand some of the poetic aspects. My main translator, Uraan Surui, is a master at relating Portuguese grammatical terms with the functions of words in the Paiter Tupi-Mondé language. The process of unveiling aspects of Paiter Suruí poetic art is long and very complex. It is thus important to catalog and classify the sonorous treasures of the Suruí Archive, even though many singers, pajés and narrators are not available either because they have passed away or have converted to Evangelism, giving up their pajelança $a^{12}$ and storytelling practices.

Workshops in Suruí territory between 2005 and 2008, were an opportunity to put the korub ey side by side with young indigenous teachers in intercultural meetings as requested by the association that cares for the interests of the Paiter Suruí. This made it possible to follow the process of normalization

12 pajelança-shamanism, the act of curing someone with herbs, songs and smoke. 
of the language, conduct transcriptions and translations of the material together with the Paiter Surui and listen closely to the sounds of the language. These meetings originated comprehension of a multifaceted panorama with several forms of vocal expression of the Paiter Surui, which, according to their own concepts, allowed me to reach the following classification that I divided into the four categories I describe below.

1. SONOROUS MYTHOLOGIQUES - function of telling stories and myths.

What I call sonorous mythologiques is the core of the Surui orality where the vocality presents elements of great wealth such as ideophones and onomatopoeia, which bring to the mythical speech a strong dramatic appeal and promotes a special musicality. The mythic narratives are based in the remote past as well as in recent events. Some myths may have songs interspersed in the narrative - like musical comments on a situation -, characters speeches or a kind of sonorization of some movement. They are divided in two styles:

MATERED EY PEREWAWE - songs of ancestry

GOXOR EY EWA - traditional chants of other peoples, borrowed by the Suruí.

2. EVERYDAY RITES - working chants related to production rituals.

Daily activities such as fishing, building a house, picking fruit in the forest that, when ritualized, gain another dimension. These songs have a role in preparing the important ceremonies in the villages, like celebrating harvests or victories.

LAB MAÃ EWA - song about making houses, building new ocas ${ }^{13}$

MOKÃIKARAREH EWA - wood chopping song, part of Mapimãi

ITXAGAEWA - fishing song using the timbo ${ }^{14}$ resource

KADEG EY EWA - palm nut (coquinho, in Portuguese) harvesting song

3. RITUAL CHANTS - used at festivals, rituals and ceremonial exchanges.

These chants are more directly linked to the ceremonies of the traditional festivals. It is not known whether they are authorial or collective, but they refer to ritual activities like body painting, the Mapimaí (group work projects)

13 oca: hut, native house made with straw and wood. The word has its origin in the Tupi-Guarani language. Huts are built collectively and are usually big, reaching 40 meters in length. The size is justified because several families inhabit the same place.

14 timbó - a kind of fishing technique that uses natural poison to catch and kill fish. 
and the iatir (chicha) preparation. Some of the ritual chants encountered in the Arampiã Archive are:

IATIR EWA - chicha drinking song, makaloba, fermented drink that inebriates the one of Mapimãi groups in the indigenous village.

GA MÃGARE YELEWA - chant of the task force that foregoes the Mapimãi party.

MAPIMÃI EWA - Mapimãi festival song, one of the most important Suruí rituals, in which they divide themselves in two groups: the ones from the village and the ones from the forest, who are called metare.

4. WAWÃ CHANTS - spirit chants, pajés chants. The world of the Suruí pajés is related to the curing chants (So pereiga), to the rituals for keeping away undesirable spirits, the (Pexo ey) and to the So ey ate, which ask for protection for the entire village. The songs sung by the wãwa are known by many, but it is the pajé who begins to sing, because only he is able to perceive the moment when the spirit wants to "appear."

SO EY ATE - sung during the spirits arrival ritual, the whole community goes outside the ocas to dance and accompany the music sung by the leader or pajé

SO PEREIGA - healing spirits chant

PEIXO EY - songs of the ritual to drive away unwelcome spirits

WHISTLE - spiritual communication, coded language performed by two natives using still non-deciphered sound codes.

This brief summary of the main oral genres refers to the Paiter past that few youngsters know of, because several of the rituals are no longer performed by the Paiter Suruí who are undergoing a transitory moment of great complexity. Evangelizing and illegal logging are some of the factors that have been destroying the kinship and modus vivendi of the Paiter. This process started in the late 1970 s with construction of the BR-654 highway and the successive massive migration projects led by the federal government.

The voice of the Paiter Surui has not been completely silent since these problems. Although this harrowing transition has muted the mythical chants, it has also generated a new Paiter Surui oral category: known as authorial songs, which differ from the old chants that "nobody knows who created" as Uraan well describes. 


\section{NEW GENRES}

The Paiter Surui created three new oral genres: machete songs (nabekod iwai ewa), love songs (kasarewa) and battle songs (ladni gewewa). Although they seem to have different contents and functions, they have something in common: they express a kind of friction between traditional life in the indigenous villages and the outside world, composed of FUNAI (Brazil's National Indian Agency) actions, the interventions of settlers and loggers, as well as the seductive of city goods. The main feature of these songs is that they speak from and to the people outside the village, i.e., the non-native. Uraan defines the new genres as follows:

LADNI GEWEWA - songs to the enemy, such as war chants, warnings and death threats as well as description of facts related to enemies of any kind, either non-indigenous or indigenous groups. Ladni g (singular) or lad ey (plural) have derogative connotations and demonstrate the combative spirit of the Paiter Suruí, who never exhibited a dampened spirit in light of the atrocities suffered as a result of Brazilian development policies. There are two important records of Paiter Surui warriors with a cycle of ladni gewewa that describe, step by step, the preparation for battle against the enemy.

KASAREWA - quoting Gasalab, Gãgbir clan leader, this is the "passion chant" that intermediates a romantic relationship between natives and nonnatives. They are like secret love songs of Paiter Suruí women with FUNAI workers, for example. The Kasarewa genre deals with a new aspect of Paiter Suruí life: disillusionment in love. Given the fact that marriage is previously arranged according to kinship rules, no dating is allowed except with uncles from the mother's side. Therefore, Paiter Suruí women do not have multiple boyfriends before they marry. However, since the 1980s, Funai agents attracted to Suruí women seduced them with promises of machetes and utensils. These women wound up nurturing affection for the foreign men, leading to conflicts with tradition and broken hearts, a feeling that did not seem to find a place in the Paiter Suruí villages. Consequently, the voice in this type of song does not always express innocence and love, but defiance against the ones who betrayed them. The voice becomes, then, strident and stiff, with more medium pitches and not as high and soft as in the iatir or making house songs.

NABEKOD IWAI EY EWA - Also known as contact chants, this new genre of Paiter oral art refers to conflicts between indigenous villagers and urban foreigners. It can be considered a kind of report, factual proof of the recent 
history of the Suruí, which I call "machete chronicals," a term based on the etymology: "machete-owners-song". To the Surui, the machete symbolizes the first contact with non-indigenous man, since one of the ways used to attract natives to make peaceful contact was to hang machetes in the forest to encourage them to come closer.

In the Suruí Archive, Betty Mindlin recorded 52 machete songs (nabekod iwai ey ewa), a significant number compared with 21 pajé chants, 12 love songs and 3 Mapimãi. The nabekod iwai ey ewa are only outnumbered by the mythical narratives, of which there are about 10o, and are an object of great interest among anthropologists who transcribed several Paiter Surui myths, published in the book "Vozes da Origem" in 1995.

The large number of contact chants expresses the distress of the Paiter before the men came to "change everything", generating disorder. It is interesting to note that this genre fell into disuse very quickly and was not replaced by any other genre. According to Uraan, nobody makes nabekod iwai ey ewa any longer. The Paiter Suruí now prefer to listen to popular country music (known as sertanejo in Brazil) and Evangelical hymns translated to the Paiter language.

The main feature of these three new Surui genres, Kasarewa, Nabekod iwai ey ewa and Ladni gewewa, is a melodic line of a few notes that accompany long lyrics. There are few tone variations, except at the end, when it is common to descend 5 th, revealing an aesthetic identity of Paiter Surui singing. This resource is also present in the So pereiga songs. These new songs are very similar in the way they use their voice, which almost always has a metallic timbre, stiff intonation, less relaxed, with fewer tonal nuances, which is the opposite of Paiter Surui sonorous mythologiques that gave more emphasis to the sound of the word than to the meaning. What is important about these three new genres of Paiter Suruí songs is the text, lógus is over mélos. Although this may seem to contradict their tradition, it reveals that, not influenced by feelings of love or hatred, the singing style refers to the external world, the motive of those songs. There may be some influence from the style of Brazilian sertanejo duos. The indigenous poetry looses its essential characteristics under outside influences that perform a type of "cleansing" of the deepest sound nuances. This is what can be evaluated today, given that it will take a long time for these songs to be transcribed and translated. That is because the Paiter Suruí consider them so personal that only the authors, themselves, can translate them. Work by anybody else would be considered an "invasion 
of privacy". Therefore, the meanings of these songs will remain hidden until future generations can master the grammar and better understand Paiter Surui history. In 2011, after five years of work with their narratives and songs, one Paiter Surui clan - the Gapgir ey - were able to produce and release the book "Gapgir ey Xagah: Amõ Gapgir ey Iwa Amõ Anar Segah ayap mi Materet ey mame Ikõr Nih - Gapgir ey clan Narratives and the Royal Hawk Myth - which they translated at workshops held in Cacoal. Fortunately, the archive was useful for them, and it was transformed into a sound library. In the future, the Paiter Surui will have more oral and written books about their "public and private life".

\section{REFERENCES}

BASSO, Ellen. 1985. A musical view of the universe: Kalapalo myth and ritual performance. Philadelphia: University of Pennsylvania Press.

BOHLMAN, Philip V. 2002. World Music. A very short introduction. New York: Oxford University Press.

DOKE, C.M. 1935. Bantu linguistic terminology. London: Longmans, Green. GAKAMAM SURUÍ. 2011. Gapgir ey Xagah: Amõ Gapgir ey Iwa Amõ Anar Segah ayap mi Materet ey mame Ikõr Nih. Brasília: LALI and Gabir ey Association. HILL, Jonathan. 1993. Keepers of the Sacred Chants. The poetics of ritual Power in an Amazonian Society. University of Arizona Press Tucson \& London, USA. JUNQUEIRA, Carmen. 1991. Indigenous anthropology: an introduction. São Paulo: Educ.

LÉVI-STRAUSS, Claude. 2004. Mythologiques I - The Raw and The Cooked. São Paulo: Cosac\&Naif.

PIEDADE, Acácio Tadeu de Camargo. 1997. Música Ye’pâ-Masa:fo an anthropology of the music in the High Rio Negro. Social Anthropology Masters Dissertation - Federal University of Santa Catarina, Florianópolis PUCCI, Magda Dourado. 2009. Rondonia's Paiter Suruí Oral Art. Anthropology Masters Anthropology - PUC-SP. São Paulo SEEGER, Anthony. 1987. Why Suyá sing: a musical anthropology of an Amazonian people. Cambridge: Cambridge University Press zUMTHOR, Paul. 2007. Performance, reception and reading. São Paulo: Cosac\&Naify 


\section{About the author}

Magda Pucci has graduation in Music by USP (University of São Paulo), is master in Anthropology by PUC-SP, and she is doing PhD (Doctorate in Musicology) at the University of Amsterdam. She is professor at Anhembi Morumbi University and member of ASCA - Amsterdam School of Cultural Analysis. She directs Mawaca band (www.mawaca.com.br/mawaca/english). She is author of the book for music educators 'Outras terras, outros sons' (Ed. Callis) and colaborated in Suruí book Gapgir ey clan Narratives and the Royal Hawk Myth. 